\title{
Comparing multimodal film texts. The case of the movie Fame (1980) and its remake Fame (2009)
}

\begin{abstract}
This paper focuses on the issue of comparison of two movies linked by the relationship of remaking. Its specific aim is to show that the complexity of multimodal texts, to which filmic texts and therefore remakes belong, does not prevent the analyst from examining the contrastive elements of such films and multimodal film texts in general. As a corollary, the present paper outlines a framework for a comparative multimodal analysis of two movies, the relevant illustrations coming from Fame (1980) and its remake Fame (2009). The basis of our comparative analysis is the narrative-compositional structure of filmic texts as discussed and amply illustrated in Post (2017). The sample multimodal comparative analysis presented in the last section of this paper relies on the selected instruments of Post's (2017) proposal, Krzeszowski's theory of contrastive analysis $(1967,1990)$ and Kress and Van Leeuwen's (2006) multimodal discourse analysis. This approach to film texts is compatible with Tabakowska's (2001) theory of cognitive translation, the main theoretical concept of which is Langacker's (1991) image schema, well fitting the aforementioned compositional level and the narrative-compositional of filmic texts. It is believed that with the instruments selected from the works enumerated above, it was possible to construct an interpretive model capable of revealing relevant differences and similarities between two multimodal filmic texts linked by the relationship of remaking.
\end{abstract}

Keywords: remake, film text, narrative-compositional structure, multimodality, multimodal text analysis.

\section{Subject matter and the research perspective}

The aim proper of this paper is to present a model of a comparative analysis of multimodal film texts. The illustrations and support for our model come from the movie Fame (Alan Parker 1980) and its remake Fame (Kevin Tancharoen 2009). From the viewpoint of the relationship of equivalence, the source film and its remake represent the case of two texts linked by the relation in question. In the presented model of comparative analysis the content of the relationship of equivalence can be adequately defined in terms of Langacker's (1991) image schemas.

1 Address for correspondence: The Philological School of Higher Education, ul. Sienkiewicza 32, 50-335 Wrocław, Poland. E-mail: anna.lisiecka17@gmail.com. 
The foundation of the proposed model of comparative analysis is the movies' narrative-compositional structure. As regards the view of general internal structure of texts, it has been abstracted from the literary and linguistic genological researches of Skwarczyńska (1965), Gajda (2008), Witosz (2005), Ostaszewska \& Cudak (2008), and Post (2014). For the comparative framework outlined in this paper, we have followed the theories proposed by Krajka \& Zgorzelski (1974), and Post (2017). The former proposal has been offered for analyses of literature, while the latter for analyses of film texts.

We view movies as multimodal texts, i.e. texts that use three semiotic codes or modes pictures, sounds and language. The three jointly create the multimodal messages. More precisely, in the movies the message for the viewers emerges from the message chunks composed of moving pictures, language, and sounds (cf. Bateman \& Schmidt 2012; Burn 2013; Wildfeuer 2014; Post 2017). The multimodal parts of our analysis have been backed up by the researches of such scholars as Kress and Van Leuwen (2006), Burn (2013), Wildfeuer (2014), and Bateman (2014) who advocate the multimodal approach to film texts as an adequate method for film text interpretations.

The proposed model of comparative analysis reveals the contrastive aspects of the selected film texts with the instruments borrowed from the works by such outstanding Polish contrastivists as Jacek Fisiak, Tomasz P. Krzeszowski, Barbara Lewandowska-Tomaszczyk and Aleksander Szwedek, to name the main scholars. In particular, the proposal of this paper applies the basic principles of the contrastive analysis as elaborated by Fisiak (1991), Krzeszowski (1967, 1992), and Morciniec (2014). The central theoretical tools of this approach to comparison of languages are the three-step comparative procedure, Tertium Comparationis and the relationships of equivalence.

The present paper consists of three basic parts. In the following section, 2, we discuss the foundations of film text analysis. Section 3 surveys the specific, selected instruments of comparative analysis of film texts. Section 4 is devoted to an exemplary comparison of the selected movies.

\section{Foundations of film text analysis}

The idea that films are texts is evidenced by different explanations and definitions, which extend from metaphorical to non-metaphorical ones. For instance, Garry Gillard (2016, online) adheres to the former view. He maintains that '[...] the notion of 'film as text' is a metaphor drawn from the idea of reading a book. It suggests that in many ways reading a book is like watching a film, and that we might take some of the things we know about the one and apply them to the other".

We follow the non-metaphorical understanding of the concept of text as explained in detail in Post (2017). The aspect that is common for both literary and non-literary texts is their general internal structure (see Post 2013, 2017). It consists of the same levels shared by language and film texts. However, they do not have the same hierarchical structure. Depending on the scholar's goal, a particular level can be the center and enter the interaction with the other levels. For the purpose of our comparative analysis we chose the narrative-compositional structure as central to films of all narrative genres. 
The film text structure is both linear and hierarchical. The general narrative-compositional structure has its origin in ancient times, specifically, in Aristotle's claim that a good story has its beginning, middle and end (Aristotle 1983 [ca. $335 \mathrm{BC}$ ]). However, his suggestion is not detailed enough for the compositional analysis of movies. As a result, we have adopted the elaborate divisions by Krajka \& Zgorzelski (1974), who distinguished seven segments of the narrative: PROLOGUE, EXPOSITION, INCITING MOMENT, DEVELOPMENT OF THE ACTION, CLIMAX, DENOUEMENT and EPILOGUE. As regards the overall compositional structure of film texts, the highest level of their narrative-compositional structures consists of three elements, such as the opening metaframe, text proper and the closing metaframe (see Post 2017).

For our detailed comparative analysis, the theory of MOVES and Steps by Swales (1990) has also been adopted. According to this point of view, the metaframes and the text proper consist of their MOVES, and MOVES in turn have their representation in Steps, which create the ultimate level of the compositional hierarchy (see Post 2017).

The enumerated compositional segments are correlated with the themes of the film text. After Post (2017), two understandings of themes are recognized in this paper. According to the first one, themes are the contents of each compositional segment. As a corollary, the themes of bigger compositional segments are the functions of the thematic content of smaller segments, that is, the themes of MOVES are the functions of the themes of their Steps. The second type of theme corresponds to the threads of the theory of literature. In the language text analysis the term motif is used, but for the purpose of multimodal film text analysis the term thread is more adequate. The thread-theme's content has its representation in different, consecutive segments of the compositional structure. The complete content of thread-themes is the function of the content of the segments it which it is located.

The aim of the multimodal research on text and discourse is to explain the use of different semiotic systems and tools in the creation of meaning (cf. Kress \& van Leeuwen 2006). From this point of view, the multimodal film analysis attempts to illustrate the usage of linguistic and non-linguistic elements and explain their role in telling the film stories. The multimodality of film texts is connected with three main modes which correlate with what the cinema audiences do, that is they watch the movie - visual mode, they listen to what the characters say - linguistic mode, and listen to the background music and noises - auditory mode.

From the multimodal perspective, visual modes have the primary role, because of the fact that it is through the visual narration that the story is told to the audience (Kress \& van Leeuwen 2006). The indicated three modalities form message units of variable size called Multimodal Message Chunks (see Post 2017). Such an understanding of multimodality of film texts can account for the connection of all segments of the linear and hierarchical compositional structure with the three modalities. Thus MOVES have their multimodal character because of the multimodality of their 
Steps and metaframes and the segments of the text proper in turn, derive their multimodal character from the multimodality of their MOVES (see Post 2017).

\section{The main instruments of comparative analysis of film texts}

Our model of comparative analysis of film texts is based on the three-step procedure of classical contrastive analysis as proposed by Krzeszowski (1990). The three consecutive steps of the procedure in question are DESCRIPTION, JUXTAPOSITION and COMPARISON. In linguistics research, it is required that the DESCRIPTIONS of two compared objects be executed within the same theoretical framework. The elements of such a framework for film texts have been enumerated in the preceding section and in the present one. At the JUXTPOSITION stage of the comparative analysis decisions are made about the actual elements to be subjected to comparison. Finally, the similarities and differences between the selected elements are revealed at the last stage of COMPARISON.

Two objects subjected to comparison have to share a common platform, so called Tertium Comparationis. The proposed model of the comparative analysis of film texts uses segments of narrative-compositional structure as shared grounds of comparison. To be more precise, for two compared movies this common platform can be any of the seven segments of texts proper (Krajka \& Zgorzelski 1974). Thus PROLOGUES may be examined for similarities and differences at the level of their MOVES. Also MOVES with the same narrative content may be compared in terms of Steps they involve. The prosed interpretive model uses different Tertia Comparationis, all of them being segments of narrative-compositional structure.

Two segments with shared Tertium Comparationis are bound by the relationship of equivalence. In the present paper the equivalence of the compared compositional segments of all level of narrative-compositional structure is described in terms of the concept of the image schemas (see Langacker 1991; Tabakowska 2001). The actual image schemas that we have applied come from the works of Kress \& Van Leeuwen's (2006:177). Kress and Van Leeuwen's mental constructs are directly linked with particular parts of the screen and film frame - LEFT-RIGHT, TOP-BOTTOM, CENTRE-MARGIN, FRONT-BACK. We have assumed that the enumerated film frame and screen dimensions are correlated with the following permanent information values: LEFT $\rightarrow$ GIVEN and RIGHT $\rightarrow$ NEW; TOP $\rightarrow$ IDEAL and BOTTOM $\rightarrow$ REAL; CENTRE $\rightarrow$ SALIENT and MARGINs $\rightarrow$ LESS or NON-SALIENT; FRONT $\rightarrow$ SALIENT and BACK $\rightarrow$ LESS or NON-SALIENT.

\section{Exemplary comparison of the selected movies}

Our exemplary comparison of the original movie and its remake focuses on their two aspects, which are (i) the selected equivalent segments of their narrative-compositional structures and (ii) the themes linked with these selected segments. Our exemplary comparative analysis is consistent with the general patterns of such comparisons as outlined in Post (2017). 


\subsection{Comparison at the level of narrative-compositional structures}

The actually selected segments of the narrative-compositional structures of the two movies, that is Alan Parker's Fame (1980) and its remake, Kevin Tancharoen movie of the same title, Fame (2009), are their EXPOSITIONS.

According to the generally accepted view (cf. for example Krajka \& Zgorzelski 1974; Głowiński et al. 1975), the role of EXPOSITIONS is to insert important initial background information about the film's story, that is, information about the setting, characters' backgrounds, prior events, general historical background, etc. In general EXPOSITIONS contain the elements that introduce the film's actions. The texts proper of both selected movies have their EXPOSITIONS, contain the same elements crucial to the story told by the films, however, the remake manages them in a way different from its filmic predecessor.

The EXPOSITION of the original movie (Fame, 1980) illustrates the main relationships and conflicts that occur in the movie. At the very beginning of the EXPOSITION, the viewers see the lunchroom where students sing, dance and play musical instruments in order to demonstrate their skills and talents. It shows the students as spontaneous and multitalented youngsters. While most of the students enjoy themselves in the lunchroom, Doris decides to leave, because she does not feel comfortable in such a place and company. At the staircase she meets Montgomery who is similarly dissatisfied. Their meeting makes them become close friends.

Other, new friendships come to be established too. Longing for success, Coco tries to convince Bruno to establish a band with her. However, he is focused on his music only and does not want to show it to the public. At the same time, Doris, Montgomery and Ralph prepare for a performance of a theatre play. At first, Ralph teases them but later they accept his behavior and get on with him well.

There are conflicts too. At the English classes, the viewers watch one of the main conflicts of the movie, the one involving Leroy and the English teacher. Leroy is a poor student who gets into the art school by accident. He is a very good dancer but he is illiterate. Also Bruno and his father are in conflict. Bruno's father is angry with him, because his son does not want to play his music in public and, what is more, he does not have any friends. Bruno tries to explain to his father that only music is important to him. Finally, the viewers watch the conflict between Lisa and Miss. Berg. Lisa has been a dancer since her early childhood. Therefore, she believes that she does not have to work hard during her dance classes, which attitude Miss. Berg does not accept.

The above content of the movie's EXPOSITION has been given the following narrative-compositional structure.

EXPOSITION (Alan Parker's Fame (1980))

MOVE 3 The lunchroom

Step 1 Students demonstrate their talents

Step 2 Doris meets Montgomery at the staircase

MOVE 4 New relationships 
Step 1 Coco encourages Bruno to establish a band

Step 2 Doris and Montgomery become closer friends during their acting in the same play.

Step 3 Doris and Montgomery become close friends with Ralph

MOVE 5 Conflicts

Step 1 The illiterate Leroy is in a conflict with his English teacher

Step 2 Bruno is in a conflict with his father, because he does not want to play his music in public

Step 3 Miss. Berg thinks Lisa is too weak to become a professional dancer

The remake's EXPOSITION (Fame 2009) also shows the students in their lunchroom, where they sing, dance and play musical instruments for the same purpose of showing their talents and skills. Denise does not feel comfortable in this place and decide to leave it. At the staircase she meets Malik who does not like the atmosphere of the lunchroom either. It follows from their conversation that Denise has very intolerant parents who do not like her focusing on too many things at the same time. Malik, in turn, tells her that his mother does not know about his art school, because she thinks that such a school is not good for her son. The meeting brings Denise and Malik close to each other and they become good friends eventually.

At the same time, Malik's mother opens the letter from the school with the grades that Malik received. To her surprise, she finds out that her son attends an art school, which makes her angry. Malik tries to convince his mother that he is an art-predisposed student but she would not listen to him. Angry, she leaves Malik alone.

The remake's EXPOSITION has arranged the above content in the following narrative-compositional structure.

EXPOSITION (Kevin Tancharoen's Fame (2009))

MOVE 3 The lunchroom

Step 1 Students demonstrate their talents

Step 2 Denise and Malik meet at the staircase

MOVE 4 Conflicts

Step 1 Malik's mum reluctantly learns about Malik's art school

Step 2 The quarrel between Malik and his mother

The above discussion represents the DESCRIPTION stage of the comparative procedure.

The EXPOSITIONS in both movies are very much similar to each other. The re-make (Fame 2009) includes the key elements of the original movie. Both of the movies share similar content and information. The time and place of the actions are also similar. In both movies, students present their talents in the lunchroom and the main characters meet at the staircase. The EXPOSITIONS also include elements about the proceeding conflicts between the characters. The narrativecompositional correlations between the EXPOSITIONS of the two movies are illustrated by the 
table below, which is meant to represent the second part of the comparative procedure, namely its JUXTAPOSITION.

Table 1. JUXTAPOSTION of the narrative-compositional structures of the EXPOSITIONS of Fame (1980) and its remake Fame (2009)

Fame $1980 \quad$ Fame 2009

\begin{tabular}{lllr}
\hline MOVE 3 & The lunch room & The lunch room & MOVE 3 \\
\hline Step 1 & $\begin{array}{l}\text { Students demonstrate their } \\
\text { talents }\end{array}$ & $\begin{array}{l}\text { Students demonstrate their } \\
\text { talents }\end{array}$ & Step 1
\end{tabular}

\begin{tabular}{llll} 
Step 2 & $\begin{array}{l}\text { Doris meets Montgomery at } \\
\text { the staircase }\end{array}$ & $\begin{array}{l}\text { Denise and Malik meet at the } \\
\text { staircase }\end{array}$ & Step 2 \\
\hline MOVE 4 & Relationships & Conflicts & MOVE 4 \\
\hline
\end{tabular}

\begin{tabular}{llll}
\hline Step 1 & $\begin{array}{l}\text { Coco encourages Bruno to } \\
\text { set the band }\end{array}$ & $\begin{array}{l}\text { Malik's mother reluctantly learns } \\
\text { about her son's art school }\end{array}$ & Step 1 \\
\hline Step 2 & $\begin{array}{l}\text { Doris and Montgomery } \\
\text { become closer friends } \\
\text { during their acting in the } \\
\text { same play }\end{array}$ & $\begin{array}{l}\text { The quarrel between Malik and } \\
\text { his mother }\end{array}$ & Step 2 \\
\end{tabular}

$\begin{array}{ll}\text { Step } 3 & \begin{array}{l}\text { Doris and Montgomery } \\ \text { become close friends with } \\ \text { Ralph }\end{array}\end{array}$

MOVE 5 Conflicts

$\begin{array}{ll}\text { Step } 1 & \begin{array}{l}\text { The illiterate Leroy is in a } \\ \text { conflict with his English } \\ \text { teacher }\end{array} \\ \text { Step } 2 & \begin{array}{l}\text { Bruno is in a conflict with } \\ \text { his father because he does } \\ \text { not want to play his music } \\ \text { in public }\end{array}\end{array}$

Step 3 Miss. Berg thinks that Lisa is too week to become a professional dancer 
Below we have presented a relatively detailed discussion of Table 1, which is meant to constitute the third part of the comparative analysis, namely COMPARISON. Table 1 shows that both EXPOSITIONS do not contain the same number of MOVES; however, they share some similarities. In some cases MOVES and Steps of both movies correlate with each other: MOVE $3=$ MOVE 3; MOVE 3 Step 1 (Fame 1980) = MOVE 3 Step 1 (Fame 2009); MOVE 3 Step 2 (Fame 1980) = MOVE 3-Step 2 (Fame 2009); MOVE 5 = MOVE 4. MOVE 4 of Fame (1980) does not have its equivalent in the re-make. It shows the relationships between the main characters, which are not highlighted in the remake. MOVE 5 of Fame (1980) illustrates all main conflicts that occur in the movie, which are the content of MOVE 4 of the remake (Fame 2009).

The similarity of narrative-compositional structures of EXPOSITIONS can also be detected at the level of Steps. For instance, Step lof MOVE 1 shows the students in the lunchroom, where they suddenly start to dance, sing and play musical instruments. This segment shows how multitalented they are. Step 1 of MOVE 1 has a direct narrative-compositional counterpart in the remake.

The others correlations of Steps in the EXPOSITIONS are as follows: Step 2 of MOVE 3 in which, not feeling comfortable in the lunchroom, Doris leaves the room and meets Montgomery at the staircase, who shares her feelings. They talk and eventually become friends. Step 2 of MOVE 3 shows Denise, who feeling uncomfortable in the lunchroom, leaves the place and meets Malik at the staircase. During this meeting she confesses that she plays the piano because her dad makes her do it. In turn, Malik admits that his mother does not know that he attends the art school.

The last correlation holds between and Step 2 of MOVE 5 (Fame 1980) and Step 1 and 2 of MOVE 4 (Fame 2009). Step 2 of MOVE 5 illustrates the conflict between Bruno and his father. Bruno creates music and nothing else is important to him. However, his father wants him to play his music to the public. In his opinion, without the audience Bruno would never be famous. Step 1 and 2 of MOVE 4 present the conflict between Malik and his mother. By accident and to her dismay, she finds out that her son attends the art school. She believes that does not bring him money in the future and does not want to believe that he is really gifted student.

Naturally, the narrative-compositional structures of both movies also differ, because it is consistent with and required by the nature of the remake. For example, Table 1 shows that the EXPOSITION of the movie Fame (2009), including the key elements of the original movie, is less elaborate in its narrative-compositional structure than the movie Fame (1980). However, a detailed enumeration of the differences goes beyond the methodological goal of the present paper.

\subsection{Comparison at the thematic level}

As indicated in section 2, for our comparative model we have adopted two understandings of the concept of 'theme' (cf. Post 2017). According to the first one, themes convey the content of MOVES (Macro Themes) and Steps (Micro Themes), which present the episodes of the movie one after another. Macro Themes refers to the most general themes and they are on the highest position in the hierarchy, whereas, the Micro Themes are the realization of the selected Macro Themes. The notation adopted for such themes is short phrases and simple sentences. The complete content 
of the EXPOSITION of Alan Parker's Fame (1980) has already been represented in section 4.1. For the sake of convenience, we repeat it below, all the themes associated with specific compositional segments being explicitly marked.

\section{EXPOSITION}

MOVE 3 The lunchroom (Macro theme)

Step 1 Students demonstrate their talents (Micro theme 1)

Step 2 Doris meets Montgomery at the staircase (Micro theme 2)

MOVE 4 Relationships (Macro theme)

Step 1 Coco and Bruno (Micro theme 1)

Step 2 Doris and Montgomery (Micro theme 1)

Step 3 Doris, Montgomery and Ralph (Micro theme 3)

MOVE 5 Conflicts (Macro theme)

Step 1 Leroy and Mrs. Sherwood (Micro theme 1)

Step 2 Bruno and his father (Micro theme 2)

Step 3 Lisa and Miss. Berg (Micro theme 3)

Below we present the entire content of the EXPOSITION of Kevin Tancharoen's Fame (2009) as represented by its themes, all being associated with specific compositional segments.

\section{EXPOSITION}

MOVE 3 The lunchroom (Macro theme)

Step 1 Students demonstrate their talents (Micro theme 1)

Step 2 Denis and Malik meet at the staircase (Micro theme 2)

MOVE 4 Conflicts (Macro Theme)

Step 1 Malik's reluctantly learns about Malik's art school (Micro theme 1)

Step 2 The quarrel between Malik and his mother (Micro theme 2)

In section 1 we said that from the viewpoint of the relationship of equivalence, the source film (Fame 1980) and its remake (Fame 2009) represent the case of two film texts linked by the relation in question. In the presented model of comparative analysis the content of the segments linked by the relationship of thematic equivalence can be adequately defined in terms of Langackerian image schemas. For the exemplary analysis, we have selected the micro theme 'Doris meets Montgomery at the staircase', linked with Step 2 of MOVE 3 and the micro theme 'Denis and Malik meet at the staircase', linked with Step 2 of MOVE 3 of the remake. The presentation below is more than sketchy as it meant to illustrate only the postulated method.

In both movies the characters meet, sit and talk at the staircase, therefore the relevant films frames focus on the two pairs of main characters. The analyzed scenes are based on dialogues 
rather than on the action. Nevertheless, the visual composition of the analyzed scenes conveys a lot of additional information.

The frame of Doris and Montgomery is based on FIGURE-GROUND scheme, the LEFT-RIGHT scheme and the GIVEN-NEW scheme. We suggest that Montgomery is the FIGURE, while Doris and the other elements of the staircase create the GROUND. At the same time, the LEFT $\rightarrow$ GIVEN and RIGHT $\rightarrow$ NEW schemas are employed. Doris is presented on the LEFT, which indicates her as temporarily less prominent character, while the RIGHT part of the frame, at which Montgomery is located, implies that he is the key character in this frame.

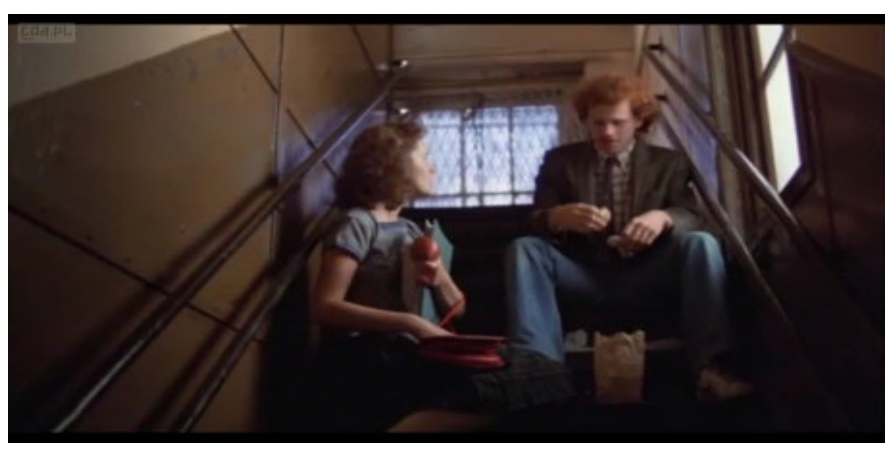

Scene 1. Doris and Montgomery on the staircase

In the frames with Denise and Malik, the same FIGURE-GRUND, LEFT-RIGHT and GIVENNEW schemas have been applied. Doris and Malik are presented as the FIGURE of this part of the movie, while the GROUND is the staircase and the part of the corridor. In the LEFT $\rightarrow$ GIVEN and RIGHT $\rightarrow$ NEW schemas, the school staircase is shown an obvious and less important part than the RIGHT part of the frame, which shows Denise and Malik as the new and key elements in this frame, to whom the attention should be paid.

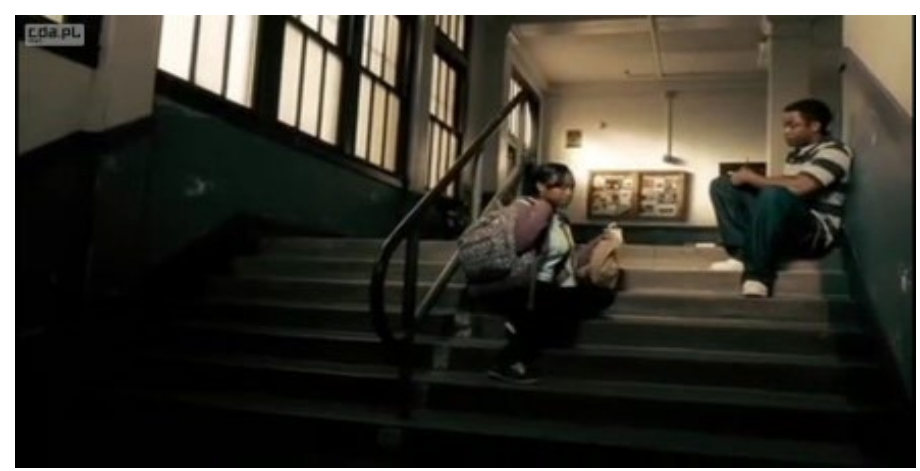

Scene 2. Denise and Malik on the staircase

As indicated above, for our comparative model we have adopted two understandings of the concept of 'theme' (cf. Post 2017). According to the second one, themes are "threads" (Pol. watki), which spread over the entire narrative-compositional structures. Below we have listed "threadthemes" that are connected with the main characters of the discussed movies. In both sets, 1 and 2 illustrate the central "thread-themes", whereas 3 and 4 are the peripheral ones. 


\section{Fame (1980)}

1. Bruno's outrageous attitude to music

2. Doris' problems with the relationships

3. Lisa's willingness to become a professional dancer

4. Lisa's difficult family situation

\section{Fame (2009)}

1. Victor 's outrageous attitude to music

2. Jenny's problems with the relationship

3. Kevin's willingness to become a professional dancer

4. Malik's difficult family situation

Below we discuss the spread over the narrative-compositional structure of the "thread-theme" 1 illustrating Bruno's and Victor's attitudes to music, in Fame (1980) and its re-make, respectively. Both of them involve much of the narrative-compositional structure. The attitude to music in the former movie has been encoded in four compositional segments of the text proper, which are: PROLOGUE, EXPOSITION, INCITING MOMENT and EPILOGUE. In the PROLOGUE, Bruno is introduced the main character endowed with the extraordinary talent for music (MOVE 1 Step 1 and 3). Next, Bruno's relationship with Coco is presented in EXPOSITION (MOVE 4 Step 1) and in the INCITING MMOMENT (MOVE 6 Step 1). In the EXPOSITION and the INCITING MOMENT, Bruno's conflict with his father over his music is shown (MOVE 5 Step 2; MOVE 6 Step 1; MOVE 7 Step 5). As regards Bruno's conflict with Mr. Shorofsky, the INCITING MOMENT hosts it (MOVE 7 Step 2). Finally, in the EPILOGUE, Bruno decides to play his music publicly (MOVE 14 Step 3). The table below shows the spread of the "thread-theme" 'Bruno's outrageous attitude to music' over the narrative-compositional structure of Fame (1980).

Table 2. The spread of the "thread-theme" 'Bruno's outrageous attitude to music' over the narrative-compositional structure of Fame (1980)
Thread-theme-
MOVE
Step
Micro-themes

Bruno's outrageous

attitude to music

$\begin{array}{lll}\text { PROLOGUE } & 1,3 \quad \begin{array}{l}\text { Bruno goes on the audition to present } \\ \text { his electronic music to the conservative } \\ \text { teacher Mr. Shorofsky }\end{array}\end{array}$




\begin{tabular}{|c|c|c|c|}
\hline EXPOSITION & 4 & 1 & $\begin{array}{l}\text { Coco is trying to encourage Bruno } \\
\text { to create a band with her but he isn't } \\
\text { interested. }\end{array}$ \\
\hline \multirow[t]{3}{*}{$\begin{array}{l}\text { INCITING } \\
\text { MOMENT }\end{array}$} & 5 & 2 & $\begin{array}{l}\text { Bruno has a quarrel with his father } \\
\text { because of the lack of having friends } \\
\text { and his reluctance to perform his music } \\
\text { in public. }\end{array}$ \\
\hline & 6 & 1,2 & $\begin{array}{l}\text { Coco and Bruno spend some time } \\
\text { together. On music classes, Bruno } \\
\text { makes Mr. Shorofsky angry because of } \\
\text { his playing the violin }\end{array}$ \\
\hline & 7 & 2 & $\begin{array}{l}\text { Bruno and Mr. Shorofsky debate about } \\
\text { the idea of traditional orchestra and } \\
\text { synthesized instruments }\end{array}$ \\
\hline EPILOGUE & 14 & 3 & $\begin{array}{l}\text { Bruno plays his music sharing it with } \\
\text { others. }\end{array}$ \\
\hline
\end{tabular}

In the movie Fame (2009), the attitude to music occupies two narrative-compositional segments of the text proper. They are PROLOGUE and INCITING MOMENT. In the PROLOGUE, Victor is presented as one of the main character and also as an extremely talented pianist (MOVE 1 Step 4). In the INCITING MOMENT, Victor's conflict with his piano teacher Mr. Cranston is shown to the viewer. (MOVE 6 Steps 1 and 2). Table 3 shows the spread of the "thread-theme" 'Victor's outrageous attitude to music' over the narrative-compositional structure of Fame (2009).

Table 3. The spread of the "thread-theme" 'Victor's outrageous attitude to music' over the narrative-compositional structure of Fame (2009)

\begin{tabular}{llll}
$\begin{array}{l}\text { Thread-theme- } 1 \\
\text { Victor's outrageous } \\
\text { attitude to music }\end{array}$ & Step & Micro-themes \\
\hline PROLOGUE & 1 & 4 & $\begin{array}{l}\text { Victor goes on the audition to present } \\
\text { his electronic music to the conservative } \\
\text { teacher Mr. Cranston }\end{array}$ \\
\hline $\begin{array}{l}\text { INCITING } \\
\text { MOMENT }\end{array}$ & 6 & 1,2 & $\begin{array}{l}\text { The illustration of the conflict between } \\
\text { Victor and his piano teacher }\end{array}$ \\
\hline
\end{tabular}


The above tables illustrate the correlation between equivalent thread-themes of both movies and their narrative compositional structures. Comparing the information conveyed, both movies convey the same message about conflicts with piano teachers. Despite the fact that the threadtheme of the original movie is introduced in four super segments of the text proper, whereas the thread-theme of the re-make in only two.

\section{Final remarks}

The author of the article has selected relevant instruments of contrastive linguistics and applied them to a comparative analysis of film texts. It should be underlined in this context that the classical contrastive researchers were mainly focused on phonology and syntax. They did not analyze texts and discourses, from neither theoretical nor descriptive point of view. As a consequence, no comprehensive models of comparative text analysis are available. To fill this gap, a model of comparative text analysis has been designed for filmic texts and presented in this paper. For the sake of the analysis, for the illustration and support of the model, the films selected by the present author were the ones linked by the relationship of remaking. In the author's opinion, such a pair of film texts naturally satisfies the fundamental stipulation of the comparative analysis that the compared items be equivalent.

Film texts have multimodal characters. That is, such texts use three main semiotic codes: pictures, sounds and language, which modes jointly create multimodal messages. The proposed model of analysis indicates a possible way of analyzing and describing films from a multimodal linguistic point of view. As usual, it is for the reader of the present paper to decide whether the proposed model of film text comparative analysis is likely to possess the required adequacy.

\section{References}

Aristotle. 1983 [ca. 335]. Poetyka. Polish translation by Henryk Podbielski. Wrocław: Zakład Narodowy im. Ossolińskich (Biblioteka Narodowa, seria II, nr 209).

Bateman, J. A. 2014. Text and Image: A Critical Introduction to the Visual/Verbal Divide. New York/London: Routledge.

Bateman, J. A. \& Schmidt, K.-H. 2012. Multimodal Film Analysis: How Film Mean. New York/ London: Routledge.

Burn, A. 2013. The kineikonic mode: Towards a multimodal approach to moving image media. NCRM Working Paper. NCRM, London, UK. (Unpublished).

Fisiak, J. 1991. On the present status of some metatheoretical and theoretical issues in contrastive linguistics. In: J. Fisiak (ed.), Further Insights into Contrastive Analysis, 3-22. Amsterdam: John Benjamins.

Gajda, S. 2008 [1993]. Gatunkowe wzorce wypowiedzi. In: J. Bartmiński (ed.), Encyklopedia kultury polskiej XX wieku. Tom 2: Współczesny język polski, 130-142.Wrocław: Zakład Narodowy imienia Ossolińskich.

Gillard,G.2016.FilmasText.http://garrygillard.net/writing/filmastext. html(DW 13.10.2016). 
Głowiński, M., Okopień-Sławińska, A., Sławiński, J. 1975. Zarys teorii literatury. Warszawa: Wydawnictwa Szkolne i Pedagogiczne.

Krajka, W. \& Zgorzelski, A. 1974. O analizie tekstu literackiego. Lublin: Wydawnictwo UMCS.

Kress, G. R. \& Van Leeuwen, T. 2006. Reading Images: The Grammar of Virtual Design. New York/ London: Routledge.

Krzeszowski, T. P. 1967. Fundamental principles of structural contrastive studies. Glottodidactica II: 107-147.

Krzeszowski, T. P. 1990. Contrasting Languages. The Scope of Contrastive Linguistics. Berlin: Mouton de Gruyter.

Langacker, R. W. 1991. Concept, Image and Symbol: The Cognitive Basis of Grammar. Berlin/New York: Mouton de Gruyter.

Morciniec, N. 2014. Gramatyka kontrastywna. Wprowadzenie do niemiecko-polskiej gramatyki kontrastywnej. Wrocław: Wydawnictwo Wyższej Szkoły Filologicznej we Wrocławiu.

Ostaszewska, D. \& Cudak, R. (eds.) 2008. Polska genologia lingwistyczna. Warszawa: Wydawnictwo Naukowe PWN.

Parker, A. (dir.) 1980. Fame. USA: Warner Home Video. Metro-Goldwyn-Mayer.

Post, M. 2013. Speech Acts and Speech Genres. An Axiological Linguistics Perspective. Wrocław: Wydawnictwo Wyższej Szkoły Filologicznej we Wrocławiu.

Post, M. 2014. Akty i gatunki mowy. Próba wielopłaszczyznowego zbliżenia. In: P. Stelmaszczyk \& P. Cap (eds.), 197-226. Pragmatyka, retoryka, argumentacja. Obraz języka i dyskursu w naukach humanistycznych. Kraków: Universitas.

Post, M. 2017. Film jako tekst multimodalny. Założenia $i$ narzędzia jego analizy. Wrocław: Wydawnictwo Wyższej Szkoły Filologicznej.

Skwarczyńska, S. 1965/1954-1965. Wstęp do nauki o literaturze. Vols. I-III. Warszawa: Państwowy Instytut Wydawniczy.

Swales, J. 1990. Genre Analysis: English in Academic and Research Setting. Cambridge: CUP.

Tabakowska, E. 2001. Językoznawstwo kognitywne a poetyka przekładu. Kraków: Universitas.

Tancharoen, K. (dir.) 2009. Fame. USA: Lakeshore Entertainment. Metro-Goldwyn-Mayer. United Artists.

Witosz, B. 2005. Genologia lingwistyczna. Zarys problematyki. Katowice: Wydawnictwo Uniwersytetu Śląskiego.

Wildfeuer, J. 2014. Film Discourse Interpretation: Towards a New Paradigm for Multimodal Film Analysis. New York/London: Routledge.

$* * *$

Anna Lisiecka is a graduate of The Philological School of Higher Education in Wroclaw. In 2001, she defended her Master's thesis in the area of speech genres. Her current research interests focus on the multimodal analysis of texts and discourses. 